University of Nebraska - Lincoln

DigitalCommons@University of Nebraska - Lincoln

To Improve the Academy

Professional and Organizational Development Network in Higher Education

1994

Challenging Values: Conflict, Contradiction, and Pedagogy

Jacqueline Mintz

Follow this and additional works at: https://digitalcommons.unl.edu/podimproveacad

Part of the Higher Education Administration Commons

Mintz, Jacqueline, "Challenging Values: Conflict, Contradiction, and Pedagogy" (1994). To Improve the Academy. 315.

https://digitalcommons.unl.edu/podimproveacad/315

This Article is brought to you for free and open access by the Professional and Organizational Development Network in Higher Education at DigitalCommons@University of Nebraska - Lincoln. It has been accepted for inclusion in To Improve the Academy by an authorized administrator of DigitalCommons@University of Nebraska - Lincoln. 


\section{Challenging Values: Conflict, Contradiction, and Pedagogy}

\section{Jacqueline Mintz}

University of California, Berkeley

The current crises of economics, demographics, retention, and disgruntled faculty, along with the neglect of the national mission to educate our citizenry for a democratic society, offer an opportunity on the cusp of the millennium to reflect about our values and the values of traditionalAmerican education. The literature of travel and cultural studies provides new lenses to help us and our institutions expose deeply held beliefs, assumptions, and the actions that have been taken in their names. Uncovering these beliefs can enable us as educators to reconstruct a common mission through developing a dynamic pedagogy for today's students, bolstered by the energies and informed by the voices, experiences, and values of all our citizens.

Few would dispute that the academy is a place rife with conflict and contradiction. Conflict is greatly valued in higher education. Despite the current recognition of the need to recommit to a common mission in these difficult economic times (when enrollment is falling, demographics are rapidly changing, and student retention as well as maintaining academic excellence is difficult), the tensions created by strongly voiced opposition are frequently cited as the food on which higher education thrives. Gerald Graff's call to "Teach the Conflicts" (1990) reinforces this approach to education.

Contradiction, on the other hand, rather than conflict per se, seems to be an issue to which our institutions and we ourselves need to devote more attention, analysis, and active energy. I use contradiction here to 
mean the professing of some belief or opinion followed by policy or actions which argue against rather than support the ideas expressed. Cases of fundamental contradiction within the academy abound. We are very familiar with the national resurgence of attention to undergraduate education and to the equally or better publicized resistanceeven opposition - to increased teaching by faculty in many institutions across the country. Even closer to home, each of us knows colleagues who deplore teaching and others who talk about their inadequacies as teachers but seek neither to improve their skills nor to institute or support programs which might preclude similar self-confessions from the future professoriate. As Henry Louis Gates, Jr. (1990) puts it, 'the schools are a site where real contradictions and ambivalences are played out" (p. 35).

For developers and faculty, even those committed to excellence in teaching, it is difficult to clarify and pursue values on such a tortured terrain. Instructional developers, whose primary mission within their institutions is to affect teaching practices for the good of their schools while serving the needs of the individual faculty and students, must contend with a plethora of contradictions, not the least of which is promoting change within a fundamentally conservative body. Long prized rights of academic freedom and independence rationalize and protect a closed-door policy in the classroom. Perks and rewards for successful grant writing, research, and publication are said to be diminished or undermined by time spent on instructional issues. In essence, power, in the form of reputation and financial gain, blatantly reinforces a zero summing or competition for limited resources which at base contradicts the American democratic mission of an educated citizenry. Kenneth Eble (1990), after many years of observation, affirmed this negative turn away from education to power: "I am interested in the larger world where the most successful large democratic state the world has known seems to be letting the desire for power cause the neglect of the education of the majority of citizenson whom the health of that democracy depends....it is the soul of the university rather than of the students that gives me most concern" (p. 19).

In these troubled times, as we and our institutions are forced to look within to evaluate our strengths, name our weaknesses, and 
reassess our core values, I would contend that the current crisis itself may occasion an opportunity that otherwise would have passed unnoticed. What I am arguing is that in easier, superficially happier times of prosperity and growth, we rarely stop to evaluate who we are, what we are doing, and whether or not what we do is consonant with our deeper beliefs and values. It is only in times of adversity, of economic, physical, or mental suffering, that we stop to ask these questions. This posture of self-reflexivity, from both institutions and individuals, is a welcome and necessary response, enabling us to separate the debilitating contradictions from the regenerating conflicts. There is arguably nothing more central or timely to American higher education on the cusp of the new millenium than the reassessment of its essential values and goals.

\section{Cultural Challenges}

Whether applied to a national level or to local and personal levels, Mary Louise Pratt's cultural writings illustrate the research and study already being done to help us fully comprehend the background for the values which constitute American education as we know it today. In her book, Imperial Eyes: Travel Writing and Transculturation, Pratt (1992) analyzes the travel writing of seventeenth- and eighteenth-century European expansion into other worlds. Pratt explains that, unlike the sea-crossings of the fifteenth and sixteenth centuries, this was a new movement, part of the age of new science and the Enlightenment. It was intended to be a straightforward exploration of interiors, part of the "classificatory schemas that coalesced in the mid-eighteenth century into the discipline of 'natural' history" (p. 28). The project was envisioned as a benign effort for discovery and knowledge. Yet, what was intended as a nonexploitative venture to improve knowledge through locating and analyzing every species on the planet, became a reweaving of "the planet's life forms...out of the tangled thread of their life surroundings...into European-based patterns of global unity and order. The (lettered, male, European) eye that held the system could familiarize ('naturalize') new sites/sights immediately upon contact, by incorporating them into the language of the system. The differences of distance factored themselves out of the picture.....Natural history 
extracted specimens not only from their organic or ecological relations with each other, but also from their places in other peoples' economies, histories, social, and symbolic systems" (p. 31).

As collected writings from the period show, seemingly naive investigations evolved from and conformed to a particular way of systematizing and valorizing physical, and even spiritual, reality. The advancement of knowledge and education, which these classificatory efforts were avowed to promote in the eighteenth century, were not only educational but, as becomes clear in the passage quoted above, involved social, political, and personal matters as well.

This attempt at objective analysis through exploration, description, and labeling was part of a broader world view, encompassing not only natural history, but all of human knowledge. Even before these projects to classify natural life, people "like Francis Bacon really did try to organize all of knowledge into a single capacious but coherent structure [and] ...there was a race of men who could claim all of knowledge as their purview." This "creed of universal knowledge" has defined the values of American higher education until today (Gates, 1990, p. 35). James Jarrett (1991), in The Teaching of Values: Caring and Appreciation, refers to the contemporary legacy: the emphasis placed on the objective in traditional American education. Importance lies with the cognitive skills: to know that, rather than to know how. Problem solving emphasizes facts and theories, fosters binary opposities, and reveres a particular kind of logic over context and connection. Like the naturalists' specimens, academics are perennially accused of removing themselves and their research to the ivory tower, a retreat from the real world and, most important today, away from their undergraduate students. Not surprisingly, today as then, shaped by traditional Western European values, many well-intentioned educators in the United States go about their work without a conscious awareness of the assumptions and biases which, similar to those of the scientists of the new age, may be responsible for outcomes neither intended nor desired.

Education - the means to knowledge, which translates into power and authority in the United States - has created a New World elite of specific descendents of the Old World aristocracy. Henry Giroux (1990) points to the historical role of the liberal arts in 
preparing those destined to rule. In higher education it is rather like passing on an estate without the scepter. The few in the know, those holding the keys, chart the paths, map the strategies, assemble the data, choose the great books, and seize the controlling metaphors. Attesting to the persistence today of these images of dominance, Professor Theodore J. Lowi of Cornell University was recently quoted in the Chronicle of Higher Education avowing: "I would like to see the Fulbright Program become the moral equivalent of empire." These enduring images perpetuate a colonial model in higher education. None of us, regardless of the value system into which we were born, is either free or necessarily cognizant of the conceptual framework which structures our thoughts and our language. Both developers and faculty trained in the Western tradition may, for example, think themselves as impartial, as did the scientists and explorers in the seventeenth and eighteenth centuries. However, like these writers who described the peoples they encountered alternately with admiration and scom (Pratt, 1992, p. 39), colleagues describe students, on the one hand, as newfound treasures, curious blank slates, empty vessels, embodied versions of uncharted territory, and, on the other hand, as the equivalent of empty landscapes, and lazy or unresponsive natives, waiting to be developed and enlightened. These deficient kids are said to be worse than their predecessors, uncritical thinkers, and, to be sure, in need of improvement. Arguments about offering questionably remedial courses in math, languages, and writing are rife, even in institutions with the most stringent entry requirements. How can anyone really be surprised when underrepresented students say "they feel like visitors, like guests, like foreign or colonized citizens in relation to a traditional canon that fails to represent their cultural identities" (Gates, 1990, p. 35).

In his address, The Cultural Sciences, the University, and Citizenship, Hayden White (1993) held that the traditional values of American higher education cannot but perpetuate the status quo. What's more, "...the academy today is an institution of legitimation - establishing what counts as knowledge, what counts as culture" (Gates, 1990 , p. 36). It follows that if education provides the normative language (recalling Pratt's allusion to the language of the system) and conventions of a society, it works, consciously and unconsciously, to 
reproduce itself, condemning those outside and uninitiated to disfranchisement or encouraging them to seek empowerment by working against the system. Giroux (1990) writes, "The university is a place that produces a particular selection and ordering of narratives and subjectivities. It is a place that is deeply political and unarguably normative"(p. 114). Few of us would deny the essential and deeply political nature of education. Like the well-meaning missionaries bent on saving those in distant places, education is not benign or free from the self-serving needs of the system of its dominant group, the group whose historical moments and beliefs it commemorates.

\section{Beyond Conceptual Boundaries}

Today, as in the eighteenth century, many individuals raised in the Western tradition desire to improve the human condition through discovery and education. It behooves us all as Americans to first apprehend the philosophy and system of values which assumes others in need, desirous, and awaiting the change we offer. We must also consider when, to whom, and what kind of change is an improvement. By engaging in this analysis of philosophical, religious, historical, and social origins, we can confront the basis of the legitimizing rationales repeatedly employed on the side of Western interventions. In Imperial Eyes , Pratt (1992) alludes to J. M. Coetzee's analyses of the seventeenth- and eighteenth-century encounters in the Cape of Africa. Coetzee writes of the European frustrations with and vilification of native peoples as a result of the "failure to fulfill anthropological and economic expectations" (p. 45). These scientific missions, catalogings, and technologically-based experiments enact a Western paradigm of universal progress and competition which continues to control American education and exhibits a particular and partial view of life.

In order to break this cycle today, we need to bring together all of our constituencies, examine all of our beliefs and motivating values, and redefine our identity together for a mission to which we consciously choose to recommit ourselves. The time has come to reconsider the meaning of $e$ pluribus unum if we are to educate our citizens for a democratic polity in the new millenium. 


\section{A Galilean Challenge Reshaped For Post-Modern, Post-Colonial Times}

The challenge for Galileo's time was to accept what could no longer be denied: the evidence that the earth circled around the sun and that man (sic), therefore, was not positioned in the center of the universe. The rupture with traditional thinking occasioned by this major shift cannot be underestimated. Yet, the challenge for our time is not a small one. It is, once again, to decenter a dominant view from the avowed center of universal knowledge and objective truth. It is to relinquish power in order to enter as equal partners in the world community where education is not a zero sum game but a genuine opportunity to learn from other world views and educational systems. The challenge to us as educators - instructional developers and faculty-is to become conscious of our own tacit values and assumptions, to examine the beliefs and precepts of the very systems in which we were trained so as not to recreate the status quo. Empirical reality, common sense, and research tell us that many traditional practices in higher education today stand counter to our growing understanding of the world we live in. It is important for us to find a way to integrate other kinds of knowledge without eradicating differences and their relational relevance.

Paolo Freire (1977), the social critic whose work has led the way for our growing awareness of the role of education in a democratic society, has shown us the importance of education in constructing both individual and social realities. In Beyond Culture, Edward Hall (1989) asserts the need to experience other cultural selves as valid realities in order to validate our own true cultural selves. It is only by experiencing these truths that we can discover the limitations of any one particular conceptual framework: "the hidden and unstated assumptions that control our thoughts and block the unraveling of cultural processes" essential to our lives and work (1976, p. 220). These formative realizations are the starting point for our work in all the roles we play in higher education. 


\section{A Beginning Without Conclusions}

As much by the research and writing of this paper as by the living of the daily experience of contradictions in essential values in American higher education, I am convinced of the complexity of the issues and the depth of the problems confronting higher education in the United States today. Nevertheless, rather than assume the reactive or oppositional posture so common in Western thinking, I wish to offer suggestions for accepting and working with the new challenges.

In The Business of Paradigms, Joel Arthur Barker (1989) assures us that what has been successful in the past is no guarantee for the future. Therefore, in the spirit of idealism and risk-taking, I am suggesting that we begin the process by expanding ourselves and our own classroom practices in search of new conceptual frameworks. With the help of many others who have been thinking along similar lines, I have compiled a list of ways which help me to work on a pedagogy of inclusion and mutual risk-taking. I offer it as a step towards creating a new vision and process for adapting higher education to the twenty-first century. The specific examples are drawn from my experiences with teaching in humanities and interdisciplinary social science courses.

\section{Towards A New Classroom Experience}

1. It is important to discuss with colleagues and students how pedagogy is embedded in value systems. Self-reflective faculty might risk finding out the discrepancies between their beliefs and their actions. Encouraging teachers to examine how they teach and grade students whose values they do not like, those who do not like theirs, or those who do not like their subject or give it high priority in their daily lives can be very instructive in bringing discrepancies to light. Likewise, by demonstrating that inconsistency and self-evaluation are human attributes and are welcome in the classroom, faculty - along with their students - can learn more about themselves, each other, and the potential for personal knowledge and growth within an open learning environment. Thomas Angelo's and K. Patricia Cross' Classroom Assessment Techniques (1993) offers various options for assessing and beginning talk about values for classroom learning. 
2. There is an urgent need to recontextualize students. Faculty must resist the scientific impulse to unity and order at the expense of losing essential differences and connections. Carefully designed discussions and writing assignments can elicit memories, narratives, and stories which reveal who students are in addition to what they think. In her talk "Comparative Cultural Studies," given at the University of California, Berkeley in April 1993, Mary Louise Pratt suggested asking students how far back their family histories go before a second language comes, in in order to engage them not only about what they know but who they are and what they choose to tell. Information shared helps students create a dynamic for working and learning together. A questionnaire or diagnostic writing exercise at the beginning of a course can help provide information to guide in lesson planning. In addition to giving relevant academic and personal background, students can express their expectations for a course, how the course fits with their personal goals, what they believe the role of the instructor is, what successful small-group or collaborative class exercises they have participated in, which classroom strategies they are most comfortable with, and how they understand the value of higher education. Encouraging them to share their academic and free-time interests helps faculty plan interdisciplinary and creative assignments. Providing a roster with phone numbers and using a variety of group assignments allow students to know and rely on one another as colearners and teachers. Such an empathetic and connected approach to learning owes much to a feminist theory of pedagogy which does not recoil from but encourages starting from existing knowledge and personal experience.

3. Faculty and students together need to find ways to introduce and incorporate value debate rather than turning away to apparent safety. Classes can and should discuss how different and even opposing values can coexist. Simulations, role-plays, and debates give voice to contrary beliefs about difficult topics. Discussion as to whether and how it is possible to find common ground to make decisions affecting everyone is essential in a democracy. Students can consider issues confronting higher education today, such as finding a common set of values to cover scientific research, defining American literature, or constituting a general core curriculum for undergraduate education in 
the United States. Even closer to their everyday experiences, students need to talk about learning in a multicultural environment. What kinds of diversity, seen and unseen, exist in a college classroom? Do students experience a sense of a dominant value system in their own classrooms? Do students perceive themselves as insiders and/or outsiders? Pratt reminds all teachers to beware of the self-flattery of letting in the other, the underrepresented or the marginalized.

4. Students need to participate in the current debates on the structure and content of their disciplines. To enable them to become critical thinkers in the debates, faculty need to teach the critical methodologies on the undergraduate level, allowing students to experience as many analytical postures as possible. Edward Hall (1989) and Gregory Jay (1987) agree that it is impossible to hear others when a person is rooted solely in one subjectivity. Faculty can model and bring in responsible critique, encouraging their students publicly to form questions about the materials. Faculty and students together can consider why theory is valorized above experience or application. Through a variety of group and individual projects, students can construct their own questions and theories and learn to critically challenge the traditional approaches and answers. Ira Shor (1993, p. 26), a Freirean scholar, describes an education which does not encourage students to pose problems as an education which is done to students, rather than something they do. Jay (1987) shows us that, by engaging material from different subjectivities, students can demonstrate how meaning is constructed and not a given.

5. Faculty and students can benefit from recognizing the relationship of identity to both reading and writing. All readers assume a position before the text and, as Judith Fetterly pointed out at the National Council of Teachers of English Summer Institute, 1993, everyone has a master narrative: a way of seeing the world. Teachers have a critical responsibility to expose students to more than one kind of consciousness. Consequently, teachers need not only to teach different readings but also to teach different kinds of writing and have students try writing other than arguments and conventional papers. James Slevin (1992) asserts that disciplinary conventions are not "part of nature" (p. 27). It follows then that academic writing is not a natural 
law. Gates (1990) wants "to emphasize that a true decentering of the humanities can't be just a matter of new content in old forms" (p. 40).

6. Faculty can help students to value their own ideas by beginning with writing exercises before reading. Making connections through writing shows students that they needn't always look to the authorities. They can produce, not only consume, meaning. (Jay, 1987, p.798). Partner journals enable students to talk to each other on different topics without teacher involvement. Electronic mail enables reactions and stories to be written which previously would have gone untold. Jon Katz (1994, p. 1) observed in The New York Times that "All over the world, the gatekeepers are disintegrating as the few who always decided what stories the rest of us would hear are yielding to the millions telling their stories directly to one another." Teachers can help students reveal and value their own stories and ideas.

7. Teaching can include some joint planning of curricula, syllabi and course guidelines with students. Rather than teaching top down, teachers can encourage independence and respons-ability (Pryse, 1993) by giving students part ownership of the course. Teachers needn't be afraid to read something for the first time with their students. Together they can decide how to proceed with assignments and evaluation.

8. Faculty alone can demystify insider knowledge by teaching students the essential conventions of their discipline (Bizzell, 1982, p. 203). By sharing the information, the normative language, and rules with students, teachers enable them to cooperate in and shape their own education. Students need to initiate rather than be passive initiates in their academic disciplines (Slevin, 1992, p.27).

9. Teachers need to be willing to take the responsibility for offering opinions. Taking a position is not presuming expertise. Presenting the reasoning for a judgment models effective discussion for students and leads to effective writing. Even more, effective teaching is also affective teaching (Marjorie Pryse, NCTE Summer Institute, 1993). Gregory Jay (1993) contends that "Teachers can take up a position of authority in order to displace it."

10. Faculty need to intertwine pedagogy with course content. Giroux (1990) cautions teachers not to treat pedagogy as what is left over (p.122). For example, in a literature course, works from diverse 
traditions can juxtapose one another to show the connectedness of the human experience or to show different treatments and values with similar themes. Suggestions for a course in drama might be: William Shakespeare's The Tempest and Aimé Césaire's A Tempest, or Arthur Miller's Death of A Salesman and August Wilson's Fences. Literature can be paired with illustrative partners from other disciplines: Mark Twain's Tom Sawyer with Howard Zinn's A People's History of the United States. Including previously hidden literature can problematize notions of a canon and great books, or the definition of American literature. Team-teaching with someone from another discipline further shows the codependence of disciplines and models cooperative work. By cooperating with students in planning, pedagogy can be determined according to students' interests, other courses they are taking, and their expressed goals within the course. Returning to the course on drama, students might choose to apply a sociological or political theory being studied in another course to their understanding of a play; they might create a scene to add to a play, giving voice to unvoiced characters or showing what is only suggested; or, they might build a stage design or produce a video to illustrate their interpretations of a particular work.

\section{Leaping into the Future}

A new classroom experience involves taking a leap of faith into an unknown. Unlike traditional lecture learning where faculty prepared the essential information necessary to master an area of study, this more plastic and inclusive pedagogy builds from the prior and current learning and thinking of both teachers and students. It entrusts students, with teacher guidance, to undertake a process to identify, analyze, and critically evaluate the crucial issues surrounding each problem. In approaching solutions, this process emphasizes knowing how rather than knowing that. It validates students' ability to work together as learners and peer teachers, offering each other a multiplicity of experiences and visions. Above all, this new classroom experience provides the opportunity for students to trust that they can acquire skills necessary to accomplish their own educational goals. In discussing learner attitudes, values, and self-awareness, Angelo and Cross 
(1993, p. 255) refer to the 1984 Study Group on Conditions of Excellence in American Higher Education. The report verifies that students stay in school longer and are happier when they are involved with their own learning. Sharing the responsibility helps faculty to be better teachers and enables students to be more engaged in what they are working towards.

Only through an active, participatory education can students be taught to use freedom responsibly. Freedom in education must mean a freedom to, rather than a freedom from. Jay (1993), fully aware of his role in preparing students for living in a democracy, encourages students to take up their own author-ity in the classroom in order to learn to acknowledge and debate conflicting values and meanings. Rather than the ivory tower or the pastoral retreat, the classroom of today is a microcosm of the diversity and living pains of society as a whole. By working together-through open dialogue-teachers and students need to make the meaning necessary to create a common ground to live in a democratic society. An open and self-reflective pedagogy, suggested by the points outlined above, offers faculty the opportunity to disprove Eble's (1990) judgment that "We are at a place where higher education is but distantly connected with shaping a citizenry, where a general upward mobility is replaced by a narrower grasping for status and wealth, and where undergraduate education has become largely irrelevant because, in itself, it gives little promise of either" (p. 12).

\section{References}

Angelo, T. A., \& Cross, K. P. (1993). Classroom assessment techniques: A handbook for college teachers (2nd ed.). San Francisco: Jossey-Bass.

Barker, J. A. (Director). (1989). The business of paradigms. In Discovering the future [Video]. Minneapolis: Chart House International.

Bizzell, P. (1982). College composition: Initiation into the academic discourse community. Curriculum Inquiry, 12, 191-207.

Eble, K. E. (1990). The degradation of undergraduate education. New Directions for Teaching and Learning, 44, 11-19.

Freire, P. (1970). Pedagogy of the oppressed (M. B. Ramos, Trans.). New York: Herder.

Gates, H. L., Jr. (1990). The transforming of the American mind. New Directions for Teaching and Learning, 44, 33-44. 
Giroux, H. A. (1990). Liberal arts education and the struggle for public life: Dreaming about democracy. The South Atlantic Quarterly, 89(1), 113-138.

Graff, G. (1990). Teach the conflicts. The South Atlantic Quarterly, 89(1), 51-67.

Hall, E. T. (1984). Beyond culture. New York: Doubleday.

Jarrett, J. L. (1991). The teaching of values: Caring and appreciation. London: Routledge.

Jay, G. S. (1987). The subject of pedagogy: Lessons in psychoanalysis and politics. College English, 49(7), 785-800.

Jay, G. S. (1993, Spring). Symposium conducted at the National Council of Teachers of English's Summer Institute for Teachers of Literature, Myrtle Beach, South Carolina.

Katz, J. (1994, January 23). The tales they tell in cyber-space are a whole other story [Arts \& Leisure]. The New York Times, pp. 1, 30.

Pratt, M. L. (1992). Imperial eyes: Travel writing and transculturation. London: Routledge.

Pryse, M. (1993, Spring). Symposium conducted at the National Council of Teachers of English's Summer Institute for Teachers of Literature, Myrtle Beach, South Carolina.

Shor, I. (1993). Education is politics: Paulo Freire's critical pedagogy. In P. McLaren \& P. Leonards (Eds.), Paulo Freire: A critical encounter (pp. 25-35). London: Routledge.

Slevin, J. F. (1992). Genre as a social institution. In J. Trimmer \& T. Warnock (Eds.), Understanding others: Cultural and cross-cultural studies and the teaching of literature (pp. 16-34). Urbana: National Council of Teachers of English.

Watkins, B.T. (1993, September 15). Proponents outline post-cold-war role for Fulbright Program. Chronicle for Higher Education, p. A43.

White. H. (1993, Spring). The cultural sciences, the university, and citizenship. Paper presented at the Conference on Critical Theory: Education and the Nation-State, University of California, Davis, CA. 